\title{
Cyst-theca relationships in some Protoperidinium species (Peridiniales) from Scottish sea lochs
}

\author{
JANE LEWIS*, J. D. DODGE*, \& P. TETT $\dagger$ \\ *Royal Holloway College, Botany Department, Egham, Surrey, TW20 0EX. \\ †Scottish Marine Biological Association, Dunstaffnage Marine Research Laboratory, PO Box 3, Oban, Argyll, PA34 4AD, Scotland.
}

\begin{abstract}
Recent dinoflagellate cysts were collected from Scottish west coast sealoch sediments and germinated to establish cyst-theca relationships. Fourteen different Protoperidinium species have been germinated and studied using the scanning electron microscope. New cysttheca relationships are described for Protoperidinium subinerme, $P$. thorianum and ?P. hangoei.

The archeopyle of the $P$. excentricum cyst is described for the first time. The archeopyles of the cysts of $P$. pentagonum (Trinovantedinium capitatum) and $P$. leonis (Quinquecuspis concretum) have previously been described as representing the loss of the second intercalary paraplate, but are here considered to represent the loss of this paraplate and also the fourth precingular paraplate.
\end{abstract}

\section{INTRODUCTION}

Dinoflagellates have long been known to form cysts. The phenomenon was described as early as 1908 by Paulsen and received occasional mention in the phycological literature during the first half of the twentieth century. Detailed investigation was, however, not carried out until the 1960 s with the pioneering work of Evitt \& Davidson (1964) and Wall \& Dale (1968). Since then, most of the work on modern marine dinoflagellate cysts and their thecate stages has been concentrated on the bloom-forming Gonyaulax species (e.g. Anderson \& Morel 1979).

Reid $(1974,1977)$, described the distribution of some modern dinoflagellate cysts around the British Isles as found in surface scrapes of intertidal sediments. A recent review by Dale (1983) in indicating some applications of cyst research to living dinoflagellate studies, pointed to the usefulness of the integrated nature of a sediment sample. As part of a study of the ecology and taxonomy of marine planktonic dinoflagellates in Scottish west coast sea lochs, the dinoflagellate cysts present in the sediments of the lochs were investigated. Many of the cysts were successfully germinated and have given new information on the relationships between cysts and the planktonic stages.

\section{METHODS}

Sediments were collected from Lochs Creran and Melfort (Fig. 1) in April. Sediment sampling was carried out using a Craib corer (Craib, 1965) which gives relatively undisturbed cores of sediment and overlying water. The overlying water and the top $5 \mathrm{~cm}$ of sediment were taken and stored at $4^{\circ} \mathrm{C}$ for later study.
For germination of cysts, a small amount of sediment $(0.5-0.75 \mathrm{~g})$ was "sonicated" gently in seawater then passed through $63 \mu \mathrm{m}$ mesh and retained on $38 \mu \mathrm{m}$ mesh sieves. The material collected on the $38 \mu \mathrm{m}$ sieve was then washed off into a small amount of culture medium to be used for the incubation experiment and then poured into a gridded petri dish. It was examined under a light microscope and individual cysts picked out using a micropipette and placed in small incubation chambers (Wall \& Dale, 1968) or $5 \mathrm{~cm}$ watch glasses enclosed in petri dishes. The medium used for incubation was $F / 50$ (Guillard \& Ryther, 1962). The cysts were kept at $20^{\circ} \mathrm{C}$ and if they had not germinated within 5 days the experiment was abandoned.

After excystment, cyst and hatched cell were observed and photographed under the light microscope and then preserved in formalin in small containers for Scanning Electron Microscopy (S.E.M.). For S.E.M., the cyst and cell pairs were again individually picked out and mounted on Nuclepore filters. These were dehydrated in an acetone sequence and dried in a critical point drier using carbon dioxide. After splutter coating with goldpalladium, cysts and germinated cells were examined in a JEOL 25S S.E.M.

\section{RESULTS}

The Protoperidinium species listed in Table 1 have been successfully incubated. Many of these (shown by * in Table 1) repeat the discoveries of Wall \& Dale (1968). The cysts incubated of $P$. minutum and $P$. divaricatum confirm the findings of Fukuyo et al., 1977 and Matsuoka et al., 1983.

In many cases, the cyst germinated but the naked 
protoplast did not properly form its thecal plates. It seemed that the type of seawater used was important in this respect and it was found that seawater from Dunstaffnage Bay near Oban was the most suitable for germination. All the thecae hatched contained numerous small bodies which were probably storage products. In most cases, the operculum remained attached to the archeopyle of the cyst and this point of attachment is shown by broken lines around the archeopyle in Fig. 2. It is not known if the point of attachment is a consistent feature but in the cysts germinated in this study, it appeared to be. In the wild, this attachment probably does not last long and the operculum is lost or falls inside the cyst (Pl. 2, fig. 3).

\section{DESCRIPTIONS OF SPECIES THAT ARE OF SPECIAL INTEREST}

\section{Protoperidinium avellana (Meunier) Balech} (Pl. 1, figs. 1, 2; Fig. 2 a, b)

Dimensions. Theca: $50-55 \mu \mathrm{m}$ long, $45-50 \mu \mathrm{m}$ wide; cyst: $50-55 \mu \mathrm{m}$ across.

Cysts. The cysts are spherical, smooth-walled and dark brown. They have a distinct curved hexagonal archeopyle. The operculum remains attached at the short side of the archeopyle and is related to the second intercalary (2A) paraplate (Fig. 2, a, b). This cyst is known under the name Brigantedinium cariacoense (Wall) Reid.

Thecae. Seven of these delicate thecae were germinated. The rounded cells have little thecal ornamentation (PI. 1, fig. 2.). The girdle is left handed, excavated and striated (PI. 1, fig. 1.).

\section{Protoperidinium conicoides (Paulsen) Balech}

(Pl. 1, fig. 5; Fig. 2 e, f)

Dimensions. Thecae: $54 \mu \mathrm{m}$ long $54 \mu \mathrm{m}$ wide; cysts: $50 \mu \mathrm{m}$ across.

Cysts. The cysts are smooth-walled, dark brown and almost spherical. All the cysts germinated of this type had a domed apex and some also had an indented parasulcus with reflected flagellar pores. The archeopyle is six sided and appears to reflect the $2 \mathrm{~A}$ plate (Fig. 2. e, f). This cyst was described by Reid (1977) as Brigantedinium simplex and used as his type species for Brigantedinium.

Thecae. Two recognisable thecae were germinated. These were rhombic in dorsoventral view and had a deeply excavated sulcus with a characteristic twist on the left below the girdle (PI. 1, fig. 5.). Germination has not previously been achieved with this species although Wall \& Dale (1968) established a link between this cyst type and $P$. conicoides by examining specimens from the plankton.

\section{Protoperidinium excentricum (Paulsen) Balech}

(Pl. 1, fig. 6; Fig. 2g, h)

Dimensions. Thecae: $30 \mu \mathrm{m}$ long $59 \mu \mathrm{m}$ wide; cysts: $50 \mu \mathrm{m}$ across.

Cysts. The cysts are smooth-walled, pale brown and slightly dorsoventrally flattened. They have an indented parasulcus and are sometimes distinctive in the sediment due to being enclosed by the parental theca. Both of the cysts incubated in this study had old thecae present. The archeopyle is an indistinct zig-zag split (Fig. 2h) somewhat reminiscent of the ?Protoperidinium cyst

\section{Explanation of Plate 1}

Fig. 1. Ventral view of excysted thecate cell of $P$. avellana; $50 \mu \mathrm{m}$ across (Loch Melfort).

Fig. 2. Detail of surface patterning of $P$. avellana; cell shown in fig. $1(\times 4140)$.

Fig. 3. Detail of surface patterning of theca of an excysted $P$. thorianum cell; $\times 4140$ (Loch Melfort).

Fig. 4. Lateral view of excysted thecate cell of $P$. thorianum; $54 \mu \mathrm{m}$ across (Loch Creran).

Fig. 5. Ventral view of excysted thecate cell of $P$. conicoides; $54 \mu \mathrm{m}$ across (Loch Creran).

Fig. 6. Dorsal/lateral view of excysted thecate cell of $P$. excentricum; $59 \mu \mathrm{m}$ across (Loch Melfort).

Fig. 7. Epithecal view of excysted thecate cell of ?P. hangoei showing five sided $2 \mathrm{~A}$ plate; $35 \mu \mathrm{m}$ across (Loch Melfort). 

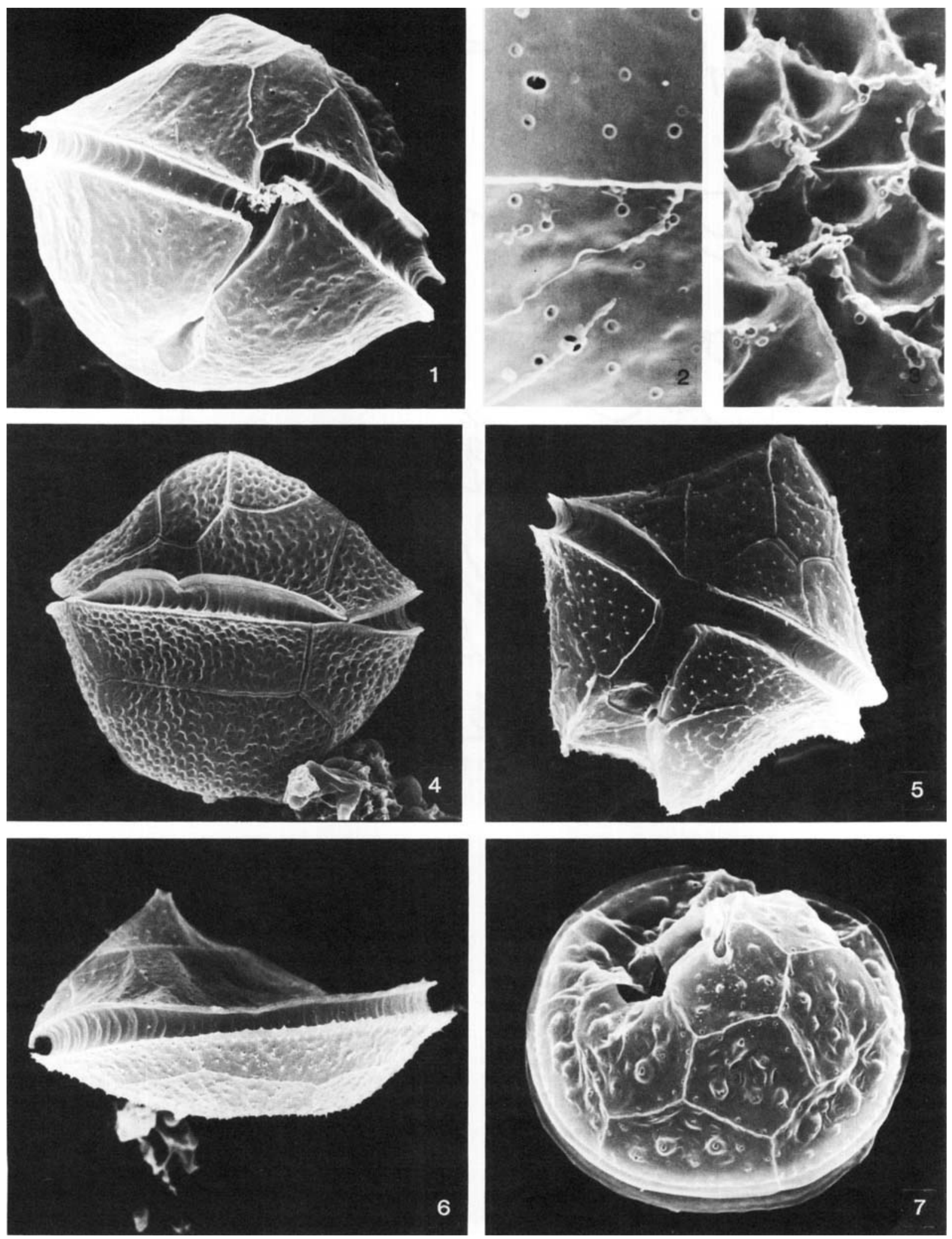


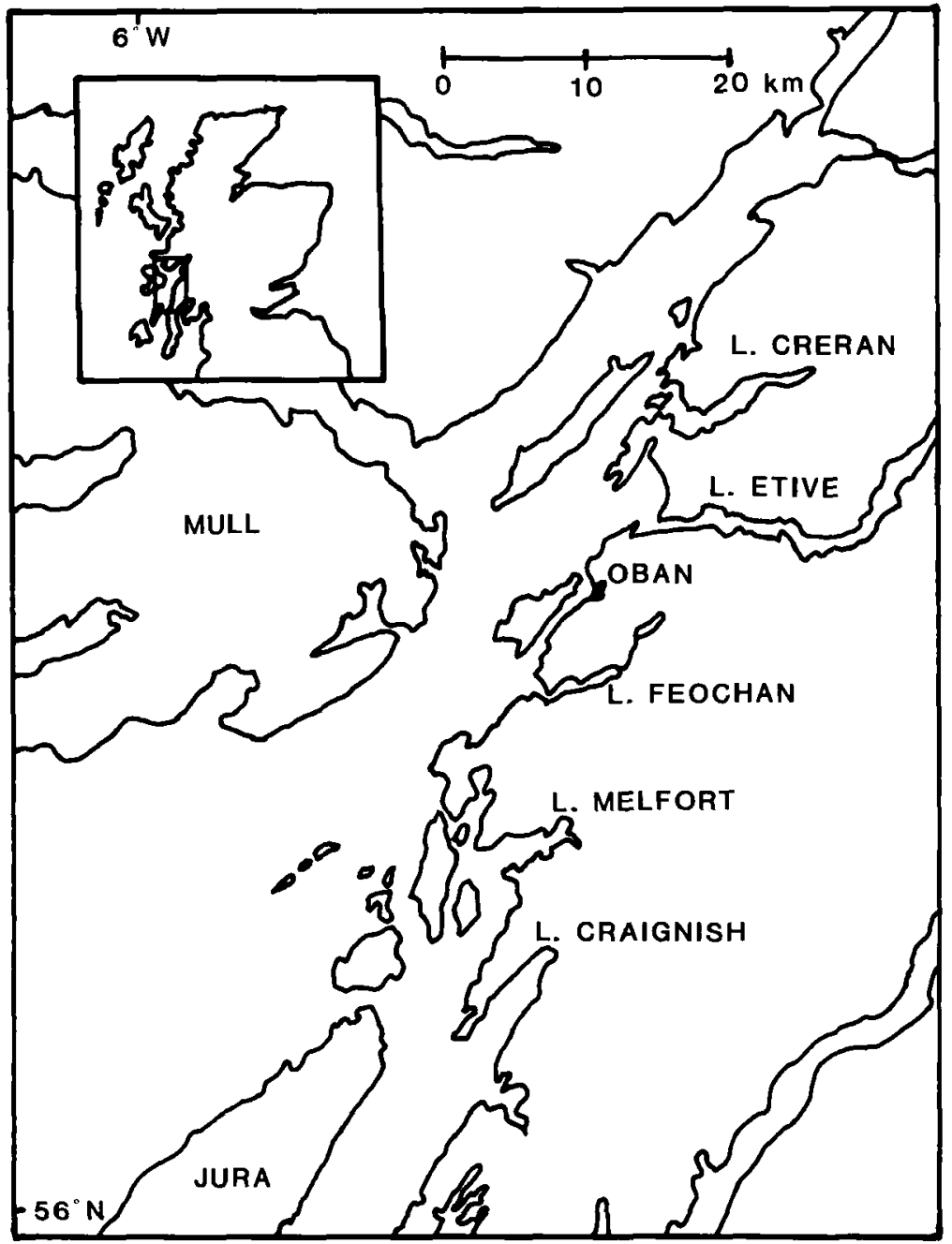

Fig. 1. Map showing location of Lochs sampled.

described by Harland (1982, Pl. 38, figs. 10-12.). It does not appear to be related to any paraplate boundaries (Fig. 2g). This cyst does not have a palynological description but is probably grouped with the other round, brown cysts of peridiniacean or glenodiniacean affinities.

Thecae. Two of the characteristically flattened thecae were germinated (PI. 1, fig. 6.).

Protoperidinium ?hangoei (Schiller) comb. nov. (Pl. 1, fig. 7; Fig. 2i, j)

Basionym: Peridinium hangoei Schiller 1937 p. 135 fig. 129 , a-d

Dimensions. Thecae: $35 \mu \mathrm{m}$ wide; cysts: $38 \mu \mathrm{m}$ across.
Cysts. The cysts are smooth-walled, brown and spherical. The hexagonal operculum remains attached to one of the short sides of the archeopyle (Fig. $2 \mathrm{j}$ ). This cyst type is so similar in appearance to those of $P$. punctulatum and various other round brown cysts that it has probably not been described as a separate cyst species.

Thecae. Two thecae were germinated. These were rounded with a slightly angular epitheca and an apical pore which extends into the third apical plate. The theca is distinguished by its three intercalary plates, the second of which is "penta" (Pl. 1, fig. 7.). The girdle is striated and excavated with small lists. The sulcus is bordered on one side by a small wing. The thecal affinity of this cell was difficult to decide. It has provisionally been ascribed to $P$. hangoei largely because of the plate patterning, 

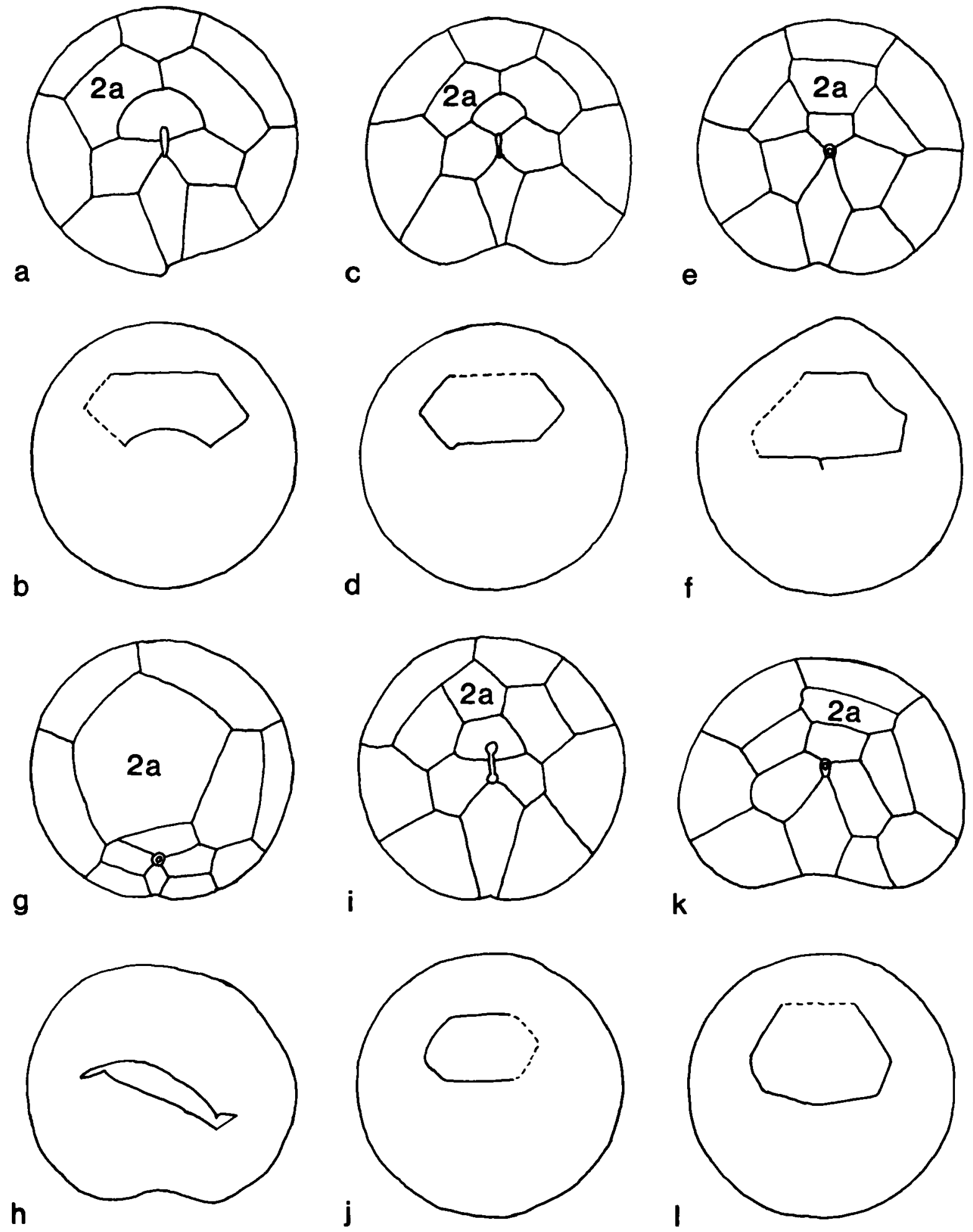

Fig. 2. Broken lines around the archeopyle denote point of attachment of operculum: a, Epithecal tabulation of $P$. avellana; b, Cyst of $P$. avellana; c, Epithecal tabulation of $P$. thorianum; d, Cyst of $P$. thorianum; e, Epithecal tabulation of $P$. conicoides; $\mathrm{f}$, Cyst of $P$. conicoides; $\mathrm{g}$, Epithecal tabulation of $P$. excentricum; h, Cyst of $P$. excentricum; $\mathrm{i}$, Epithecal tabulation of ?P. hangoei; $\mathrm{j}$, Cyst of ?P. hangoei; $\mathrm{k}$, Epithecal tabulation of P. subinerme; 1, Cyst of $P$. subinerme. 
Table 1. Protoperidinium species germinated

\begin{tabular}{|c|c|}
\hline Thecate stage & Palaeontological name for cyst \\
\hline $\begin{array}{l}{ }^{*} \text { Protoperidinium avellana } \\
\text { (Meunier) Balech }\end{array}$ & $\begin{array}{l}\text { Brigantedinium cariacoense } \\
\text { (Wall) Reid }\end{array}$ \\
\hline $\begin{array}{l}{ }^{*} P \text {. claudicans } \\
\quad \text { (Paulsen) Balech }\end{array}$ & $\begin{array}{l}\text { Votadinium spinosum } \\
\quad \text { Reid }\end{array}$ \\
\hline $\begin{array}{l}{ }^{*} P \text {. conicoides } \\
\text { (Paulsen) Balech }\end{array}$ & $\begin{array}{l}\text { Brigantedinium simplex } \\
\text { Reid }\end{array}$ \\
\hline $\begin{array}{l}{ }^{*} P . \text { conicum } \\
\quad \text { (Gran) Balech }\end{array}$ & $\begin{array}{l}\text { Selenopemphix sp. } \\
\text { Benedek }\end{array}$ \\
\hline \multicolumn{2}{|l|}{$\begin{array}{l}{ }^{*} P . \text { denticulatum } \\
\text { (Gran \& Braarud) Balech }\end{array}$} \\
\hline $\begin{array}{l}\text { P. divaricatum } \\
\text { (Meunier) Parke \& Dodge }\end{array}$ & $\begin{array}{l}\text { Xandarodinium xanthum } \\
\text { Reid }\end{array}$ \\
\hline \multicolumn{2}{|l|}{$\begin{array}{l}\text { P. excentricum } \\
\text { (Paulsen) Balech }\end{array}$} \\
\hline \multicolumn{2}{|l|}{$\begin{array}{l}\text { ?P. hangoei } \\
\text { (Schiller) comb. nov. }\end{array}$} \\
\hline $\begin{array}{l}{ }^{*} P \text {. leonis } \\
\quad \text { (Pavillard) Balech }\end{array}$ & $\begin{array}{l}\text { Quinquecuspis concretum } \\
\text { (Reid) Harland }\end{array}$ \\
\hline \multicolumn{2}{|l|}{$\begin{array}{l}P . \text { minutum } \\
\text { (Kofoid) Loeblich III }\end{array}$} \\
\hline $\begin{array}{l}{ }^{*} P . \\
\quad \text { oblongum } \\
\quad \text { (Aurivillius) Parke \& Dodge }\end{array}$ & $\begin{array}{l}\text { Votadinium calvum } \\
\quad \text { Reid }\end{array}$ \\
\hline $\begin{array}{l}{ }^{*} P . \text { pentagonum } \\
\quad \text { (Gran) Balech }\end{array}$ & $\begin{array}{l}\text { Trinovantedinium capitatum } \\
\text { Reid }\end{array}$ \\
\hline \multicolumn{2}{|l|}{$\begin{array}{l}\text { P. subinerme } \\
\text { (Paulsen) Loeblich III }\end{array}$} \\
\hline $\begin{array}{l}\text { P. thorianum } \\
\text { (Paulsen) Balech }\end{array}$ & \\
\hline
\end{tabular}

albeit the original description was drawn in mirror image (Lindemann, 1924). There are, however, a number of differences. The scanning micrograph of the excysted motile stage (PI. 1, fig. 7.) shows the theca to have some relief whereas previous descriptions of $P$. hangoei by light microscopy have shown it as smooth walled. $P$. hangoei is also drawn as being rounded but the epitheca of our specimens was slightly angular.

Protoperidinium leonis (Pavillard) Balech (Pl. 2, figs. 3, 4, 6)

Dimensions. Thecae: $60 \mu \mathrm{m}$ long, $60 \mu \mathrm{m}$ wide; cysts: $65 \mu \mathrm{m}$ long, $65 \mu \mathrm{m}$ wide.

Cysts. The cysts are pentagonal, smooth-walled and brown. They have been described in various cyst genera but Harland (1982) considers they should reside in Quinquecuspis. The archeopyle of this cyst has previously been considered to represent the loss of the $2 \mathrm{~A}$ paraplate. Evitt (1967) considered it to be a fine example of an enlarged $2 \mathrm{~A}$ archeopyle. Some doubt was expressed by Harland (1977) who postulated the involvement of the third apical paraplate. Pl. 2, fig. 3. clearly shows that the archeopyle is not simple in shape and seems to represent the loss of more than one paraplate. Its proximity to the paracingulum, and comparison with the thecate stage (Pl. 2, fig. 6.), suggests the additional loss of the fourth precingular $\left(4^{\prime \prime}\right)$ paraplate (for further discussion see under $P$. pentagonum). 
Thecae. The theca is covered with a characteristic patterning of ridges and spines enclosing a "netted" pattern and pores (Pl. 2, fig. 4). This is also seen in $P$. leonis thecae from the plankton (Dodge \& Saunders, unpubl.). The hypotheca extends to two hollow horns with a solid spine on each. As noted by several authors (Wall \& Dale 1968; and Harland, 1982) there is much variation in this cyst type and a species complex may exist. However, only one theca has been germinated and positively identified so far.

\section{Protoperidinium pentagonum (Gran) Balech}

$$
\text { (Pl. 2, figs. 1, 2, 5) }
$$

Dimensions. Thecae: $70 \mu \mathrm{m}$ long, $60 \mu \mathrm{m}$ wide; cysts: $65 \mu \mathrm{m}$ long, $60 \mu \mathrm{m}$ wide.

Cysts. The cysts are colourless, pentagonal and ornamented with capitate spines (Pl. 2, fig. 5). They are of the type Trinovantedinium capitatum (Reid). The archeopyle is hexagonal and is usually described as intercalary, however, S.E.M. illustrations of a specimen picked from the plankton with its theca attached showed clearly that the archeopyle represents the loss of the $2 \mathrm{~A}$ and the $4 "$ paraplates (Pl. 2, figs. 1, 2).

Thecae. Many thecae were hatched. Some of these resembled $P$. pentagonum but as Abé (1981) points out this is a little-studied species and can easily be confused with such species as Peridinium bidentatum Abé, $P$. expansum Abé and $P$. sinuosum (Lemmerman) Jorgensen. There were slight variations in this cyst type so it is felt that more than one species may be involved here, as implied by Wall \& Dale (1968). Some of the thecae germinated in this study and the cell in Pl. 2, fig. 1 did not appear to be $P$. pentagonum. More critical work is required to elucidate this situation.

\section{Protoperidinium subinerme (Paulsen) Loeblich III (Pl. 2, fig. 7; Fig. 2k, l)}

Dimensions. Thecae: $55 \mu \mathrm{m}$ across; cyst: $50 \mu \mathrm{m}$ across.

Cysts. The cysts are smooth, spherical and dark brown. They have a fairly large hexagonal operculum which remains attached to the long side of the archeopyle (Fig. 2l) and appears to be most closely related to the $2 \mathrm{~A}$ paraplate (Fig. 2k). These are quite unlike the cyst already described for $P$. subinerme by Wall \& Dale (1968) (Selenopemphix nephroides Benedek). This cyst type has not been found by us in Scottish sea loch sediments. It was not mentioned by Reid in his survey of U.K. sediments and did not appear to occur around the British Isles in Harland's survey of North Atlantic dinoflagellates (Harland, 1983) although $P$. subinerme is relatively common around the British Isles (Dodge,
1981). Unfortunately, no comparative work has been possible. Perhaps there is more than one variety of $P$. subinerme or a species complex with more than one cyst type involved.

Thecae. One theca was germinated and was initially thought, after light microscopy to be $P$. punctulatum. Examination by S.E.M., however, showed the theca to be $P$. subinerme. The two species are very similar but $P$. subinerme has a distinctly spiny surface and there are spines at the base of the sulcus (Pl. 2, fig. 7) unlike $P$. punctulatum which has small rounded protrusions all over the surface of the theca (Dodge and Saunders unpubl.). The plate patterns in $P$. subinerme are quite variable, and in this case the $2 \mathrm{~A}$ plate was "hexa".

\section{Protoperidinium thorianum (Paulsen) Balech (PI. 1, figs. 3, 4; Fig. 2c, d)}

Dimensions. Thecae: $50-60 \mu \mathrm{m}$ across; cysts: $50-55 \mu \mathrm{m}$ across.

Cysts. The cysts are spherical, smooth-walled and dark brown. The operculum, although similar in shape to that of P.avellana; is not curved and is attached to the archeopyle along the long side (Fig. 2d). Again it is a round, brown cyst that has probably not been described separately. It is most similar to the cysts of $P$. denticulatum.

Thecae. Three thecae were germinated. They were very similar to $P$. avellana, having two intercalary plates and a left handed, striated, excavated girdle (Fig. 2c; Pl. 1, fig. 4.). They are characterised by their papillate thecal plate surface (Pl. 1, fig. 3).

\section{DISCUSSION}

The scanning micrographs of excysted thecate motile stages show them to be identical with their counterparts in the plankton. The S.E.M. has proved an invaluable tool in this work allowing detailed examination of the few specimens usually available of each species.

When there is little or no paratabulation on the cysts it is only possible to speculate on the relationship of the archeopyle to specific paraplates. Clues provided by the examination of the $P$. pentagonum cyst with its parental thecate stage present suggest that what has been regarded as a simple archeopyle may involve two paraplates. S.E.M. illustrations of $\boldsymbol{P}$. leonis cysts suggest similarly that more than one paraplate is involved. It is felt that in both cases the $2 \mathrm{~A}$ and the 4 " paraplates are responsible.

Round brown cysts have long been a taxonomic problem. Nine Protoperidinium species have now been described as having such cysts. Before incubation or chemical treatment these cysts are indistinguishable and could also be confused with Diplopsalis cysts. After 
germination there is still confusion as many of the thecate stages have similar $2 \mathrm{~A}$ plates and hence similar archeopyles - for example the archaeperidiniums $P$. avellana, $P$. denticulatum and P.thorianum. Observations of recent empty brown spherical cysts from the sediments show that damage can cause them to have more than one opening in the cyst wall. Specimens are also indistinguishable if they are crushed or not in a favourable orientation. It is possible that they may be distinguished by size but further critical research would be needed to confirm this. They may, however, need to be separated only if the species concerned are ecologically different. Most of the species germinated in this study have been obtained from one sea loch so they all survived in approximately the same environmental conditions.

The taxonomic problems are not only confined to cysts: plate variations in the motile thecate dinoflagellates can cause some taxonomic problems. The $2 \mathrm{~A}$ plate often seems to vary. For example, in the Wall \& Dale, 1968 paper $P$. conicum is described as having a quadrate or hexagonal $2 \mathrm{~A}$ plate and is figured as being "hexa". Two thecae incubated in this study had a "quadra" 2 A plate. As all the motile cells come from the same distinctive cyst type (Selenopemphix) they should clearly belong to the same species. Conversely, many different cysts give rise to the Gonyaulax spinifera group and here perhaps there is a case for further taxonomic splitting of the thecate stages.

Differences in cyst types may also help to resolve some of the problems associated with 'species complexes', such as those of $P$. pentagonum and $P$. oblongum. Here, the more easily distinguished cysts may improve the understanding of the thecate taxonomy. Nevertheless, 'species complex' may be a more useful concept to the ecologist.
Harland (1982) showed that cyst and thecate nomenclature within the genus Protoperidinium is compatible. The new cyst-theca relations described fit into his scheme:- e.g. Protoperidinium (Archaeperidinium section Fucusphaeridinium) thorianum and Protoperidinium (Protoperidinium section Asymmetropedinium) hangoei. However, there is possible confusion over $P$. subinerme. As it is described in this paper, it fits best with Protoperidinium (Protoperidinium section Brigantedinium), along with $P$. conicoides. It will be noted that their thecal morphologies are very similar. However, the cyst described for $P$. subinerme by Wall \& Dale (1968) has been assigned to Protoperidinium (Protoperidinium section Selenopemphix). Harland referred to Xandarodinium xanthum in the 1982 paper but because of insufficient evidence was unable to place it in his scheme. Now, with the work of Matsuoka $\mathrm{et}$ al. (1983) and this paper, it seems possible that $X$. xanthum should be placed in the Selenopemphix section of Harland's scheme or more likely in a new secton of its own.

We are still far from obtaining a complete overall perspective of the relationship between Protoperidinium species and their cysts but it is clear that the taxonomy of the planktonic dinoflagellates should be studied with regard to both cyst and thecate stages to give a more natural classification.

\section{ACKNOWLEDGEMENTS}

This paper was given in part at the annual meeting of the British Phycological Society (1984). We would like to thank R. Saunders for help with S.E.M. and photography and R. Harland for helpful discussion. J. Lewis is in receipt of a N.E.R.C. CASE studentship.

\section{Explanation of Plate 2}

Fig. 1. Dorsal view of theca of $P$. pentagonum enclosing a cyst which was picked from a plankton sample taken in L. Creran in early July; $65 \mu \mathrm{m}$ across.

Fig. 2. Detail of the archeopyle and associated thecal plates of cyst/theca shown in fig. $1(\times 2600)$.

Fig. 3. A germinated cyst of $P$. leonis, $63 \mu \mathrm{m}$ across (Loch Melfort).

Fig. 4. Detail of surface patterning of excysted $P$. leonis theca $(\times 9000)$.

Fig. 5. Capitate spine of $P$. pentagonum cyst shown in fig. $1(\times 26,000)$.

Fig. 6. Dorsal view of thecate cell of $P$. leonis germinated from cyst shown in fig. 3; $59 \mu \mathrm{m}$ across.

Fig. 7. Apical view of excysted thecate cell of $P$. subinerme; $55 \mu \mathrm{m}$ across (Loch Melfort). 

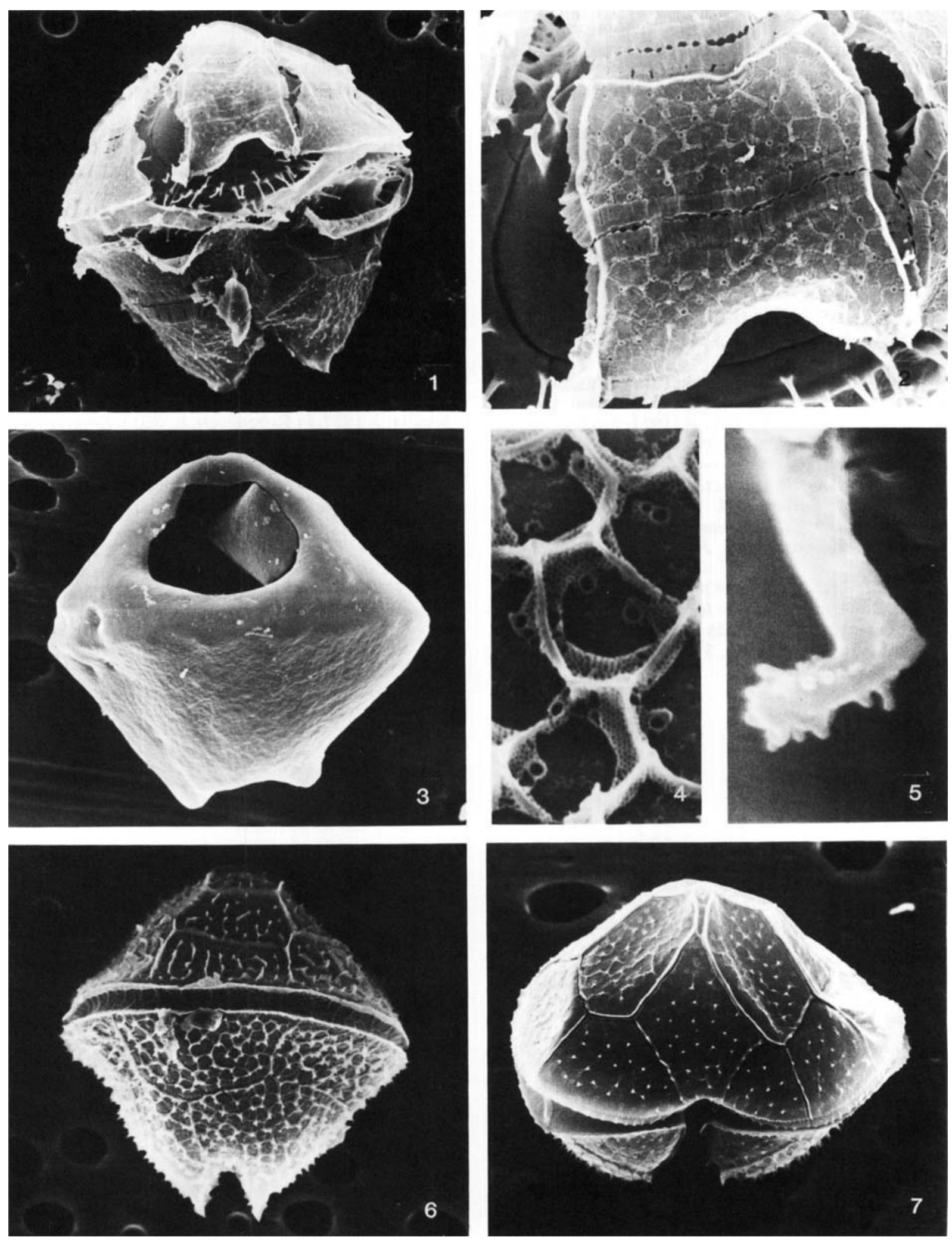


\section{REFERENCES}

Abé, T. H. 1981. Studies on the Family Peridiniidae. An unfinished monograph of the armoured Dinoflagellata. 409 pp., 65 figs. Academia Scientific Book Inc. Tokyo.

Anderson, D. M. \& Morel, F. M. M. 1979. The seeding of two red tide blooms by the germination of benthic Gonyaulax tamarensis hypnocysts. Estuarine and Coastal Marine Science, London, 8, 279-293, 5 figs.

Craib, J. S. 1965. A sampler for taking short undisturbed marine cores. J. Cons. Perm. Int. Explor. Mer., Copenhagen, 30, 34-39.

Dale, B. 1983. In Fryxell, G. A. (Ed.), Survial strategies of the Algae (4) Dinoflagellate resting cysts: "benthic plankton". pp. 69-136 46 figs., Cambridge University Press.

Dodge, J. D. 1981. Provisional Atlas of the Marine Dinoflagellates of the British Isles. 125 figs. Institute of Terrestrial Ecology. Huntingdon.

Evitt, W. R. \& Davidson, S. E. 1964. Dinoflagellate studies 1. Dinoflagellate cysts and thecae. Stanford Univ. Publ., Geol. Sci., 10, 1-12, 2 figs., 1 pl.

Evitt, W. R. 1967. Dinoflagellate studies II. The archeopyle. Stanford Univ. Publ., Geol. Sci., 10, 1-83, 50 figs., 11 pls.

Fukuyo, Y., Kittaka, J. and Hirano, R. 1977. Studies on the cysts of marine dinoflagellates I. Protoperidinium minutum (Kofoid) Loeblich. Bull. Plankton Soc. Japan, 24, 11-18, In Japanese with English abstract.

Guillard, R. R. L. \& Ryther, J. H. 1962. Studies on marine planktonic diatoms. I. Cyclotella nana Hustedt and Detonula confervacea (Cleve) Gran. Can. J. Microbiol., Ottawa, 8 , 229-239, 4 figs.

Harland, R. 1977. Recent and Late Quaternary (Flandrian and Devensian) dinoflagellate cysts from marine continental shelf sediments around the British Isles. Palaeontographica Abt. B., Stuttgart, 164, 87-126, 5 figs., 4 pls.
Harland, R. 1982. A review of Recent and Quaternary organic-walled dinoflagellate cysts of the genus Protoperidinium. Palaeontology, London, 25, 369-397, 24 figs., pls. $38-42$.

Harland, R. 1983. Distribution maps of recent dinoflagellate cysts in bottom sediments from the North Atlantic ocean and adjacent seas. Palaeontology, London, 26, 321-397, 44 figs., pls. 43-48.

Lindemann, Von. E., 1924. Ueber finnische Peridineen. Arch. Hydrobiol., Stuttgart, XV, 1-4, Taf. 1.

Matsuoka, K., Kobayashi, S. \& Ilzuka, S. 1982. Cysts of Protoperidinum divaricatum (Meunier) Parke et Dodge 1976 from surface sediments of Omura Bay, West Japan. Rev. Palaeobot. Palynol., Amsterdam, 38, 109-118, 2 figs., 2 pls.

Paulsen, O. 1908. In Brandt, K. \& Apstein, C. H. Nordisches Plankton. Botanischer Teil, XVIII Peridiniales 124 pp., 155 figs.

Reid, P.C. 1974. Gonyaulacacean dinoflagellate cysts from the British Isles. Nova Hedwigia, XXV, 579-637. 15 figs., 4 pls.

Reid, P. C. 1977. Peridiniacean and Glenodiniacean dinoflagellate cysts from the British Isles. Nova Hed wigia, XXIX, 429-463. 2 figs., 4 pls.

Schiller, J. 1937. In Rabenhorst, L. (Ed.), Kryptogamen-Flora (10) Dinoflagellatae (Peridineae). 590 pp., 612 figs. Leipzig. Wall, D. \& Dale, B. 1968. Modern dinoflagellate cysts and evolution of the Peridiniales. Micropaleontology, New York, 14, 265-304, 7 figs. 4 pls. 